\title{
AQUEOUS EXTRACT OF CARICA PAPAYA LINN ROOTS HALTS SODIUM ARSENITE-INDUCED RENAL INFLAMMATION THROUGH INHIBITING ADENOSINE DEAMINASE, 8-HYDROXY-2'-DEOXYGUANOSINE, C-REACTIVE PROTEIN AND INDUCIBLE NITRIC OXIDE SYNTHASE ACTIVITY
}

Oluwafemi Adeleke Ojo일 Adebola Busola Ojo ${ }^{2}$, Olukemi Adetutu Osukoya ${ }^{1}$, Basiru Olaitan Ajiboye ${ }^{1}$,

${ }^{1}$ Phytomedicine, Biochemical Toxicology and Diabetes Research Group, Department of Biochemistry, Afe Babalola University, Ado-Ekiti, Ekiti State, Nigeria ${ }^{2}$ Department of Medical Biochemistry, Afe Babalola University, Ado-Ekiti, Ekiti State, Nigeria

VODENI EISTRAKT KORENA CARICA PAPAYA L.ZAUSTAVLJA

INFLAMACIJU BUBREGA IZAZVANU NATRIJUM-ARSENITOM, INHIBIRAJUĆI ADENOZIN DEAMINAZU, 8-HIDROKSI-2'-DEOKSIGUANOZIN, C-REAKTIVNI PROTEIN, INOS AKTIVNOST

Oluwafemi Adeleke $\mathrm{Ojo}^{1}$, Adebola Busola Ojo ${ }^{2}$, Olukemi Adetutu Osukoya ${ }^{1}$, Basiru Olaitan Ajiboye ${ }^{1}$

${ }^{1}$ Fitomedicina, Istraživačka grupa za biohemijsku toksikologiju i dijabetes, Katedra za Biohemiju, Afe Babalola Univerzitet, Ado-Ekiti, Ekiti, Nigerija ${ }^{2}$ Katedra za medicinsku biohemiju, Afe Babalola Univerzitet, Ado-Ekiti, Ekiti, Nigerija

Received / Primljen: 28. 04. 2017.

Running title: Anti-inflammatory activity of Carica papaya root Kraći naslov: Antiinflamatorna aktivnost korena Carica papaya

Accepted / Prihvaćen: 14. 06. 2017.

\begin{abstract}
Objectives: Inflammation plays a crucial role in many of the metabolic abnormalities. The prototypic marker of inflammation is C-reactive protein (CRP), Nitric Oxide (NO), inducible nitric oxide synthase ( $\mathrm{NONS}$ ) and their inhibition is considered a promising strategy to combat inflammation. Here, we report the anti-inflammatory mechanism of Carica papaya root aqueous extract in sodium arsenic-induced renal dysfunction.

Methodology: Thirty-five rats were used for the experiments. Griess assay was used to evaluate the inhibitory effect of Carica papaya roots aqueous extract on the overproduction of nitric oxide (NO). ELISA was used to determine the level of pro-inflammatory markers including c-reactive protein (CRP). ELISA was used to analyze 8-OHdG. The inhibitory effect on the enzymatic activity of inducible nitric oxide synthase (iNOS), adenosine deaminase ( $A D A)$, malondialdehyde (MDA) was tested by enzyme activity assay kits.
\end{abstract}

Results: Carica papaya roots aqueous extract suppressed sodium arsenite-stimulated NO production and proinflammatory secretion, such as CRP. Carica papaya roots aqueous extract significantly $(p<0.05)$ decrease the activities of $i N O S$, 8-OHdG, ADA and MDA.

Conclusion: These results indicated that potent inhibition on CRP, NO, iNOS, ADA, 8-OHdG might constitute the anti-inflammatory mechanism of Carica papaya roots aqueous extract.

Keywords: Carica papaya Linn. roots, anti-inflammatory biomarkers, renal inflammation

\section{SAŽETAK}

Ciljevi: Inflamacija ima ključnu ulogu u brojnim metaboličkim poremećajima. Smatra se da inhibicija faktora inflamacije kao što su C-reaktivni protein (CRP), azot monoksid (NO), inducibilna azot monoksid sintetaza (iNOS) predstavlja obećavajuću strategiju u borbi sa inflamacijom. U ovom radu smo izvestili o antiinflamatornom mehanizmu vodenog ekstrakta korena Carica papaya kod natrijum-arsenitom izazvane bubrežne disfunkcije.

Metodologija: U eksperimentima je korišćeno 35 pacova. Griess-ov rastvor je korišćen da ispita inhibitorni efekat vodenog ekstrakta korena Carica papaya na povećanu produkciju azot monoksida. Za odredivanje nivoa proinflamatornog markera CRP-a je korišćena elisa. Elisa je korišćena za analizu 8-hidroksi-2'-deoksiguanozina (8-OHdG). Esej za analizu enzimske aktivnosti je korićen za određivanje aktivnosti iNOS, adenozin deaminaze (ADA) i malonildialdehida (MDA).

Rezultati: Vodeni ekstrakt korena Carica papaya suprimira natrijum-arsenitom stimulisanu produkciju NO i sekreciju proinflamatornih molekula kao što je CRP. Vodeni ekstrakt korena Carica papaya je statistički značajno $(p<0,05)$ smanjio akivnost iNOS, 8-OHdG, ADA $i$ MDA.

Zaključak: Ovi rezultati pokazuju da jaka inhibicija CRP, NO, iNOS, ADA, 8-OhdG može predstavljati potencijalan mehanizam antiinflamatornog delovanja vodenog ekstrakta korena Carica papaya.

Ključne reči: koren Carica papaya L., antiinflamatorni biomarkeri, bubrežna inflamacija

\section{ABBREVIATIONS}

CRP - C reactive protein; NO - Nitric oxide; iNOS - inducible nitric oxide synthase;
ADA - Adenosine deaminase;

8-OHdG - 8-hydroxy-2'-deoxyguanosine;

MDA - malonaldehyde 


\section{INTRODUCTION}

Arsenic is a ubiquitous element present in food, soil, water and air, and it is released into the environment from both anthropogenic and artificial sources $(1,2)$. The foremost inorganic forms of arsenic comprise of the trivalent meta arsenite $\mathrm{As}^{3+}$ and the pentavalent arsenate $\mathrm{As}^{5+}$. Trivalent arsenic form has a higher affinity for thiol groups and is more cytotoxic and genotoxic than $\mathrm{As}^{5+}(3,4)$. Organisms that store the trivalent intermediates are thought to be at greater risk of arsenic- induced ailments (4). Some of the organic forms contain the methylated metabolites monomethylarsonic acid (MMA), dimethylarsenic acid (DMA) and trimethylarsine oxide (TMAO) as well as arsenocholine, arsenobetaine (AsB) and arsenosugars. Over $80 \%$ of commercially employed arsenic compounds are used to manufacture products with agricultural applications for examples herbicides, fungicides, insecticides, algaecides, wood preservatives, dyestuffs, sheep dips and medicines for the eradication of tapeworms in sheep and cattle. Arsenic compounds have been used for at least a century in the treatment of yaws, amoebic dysentery, syphilis and trypanosomiasis (5).

Toxic effects of arsenic accredited to production of reactive oxygen species (ROS) and oxidative stress results in the alteration of the antioxidant defense system, increased oxidative stress and cell death $(6,7)$. Liver and kidney are target organs for arsenic toxicity in rats, though, concentration of arsenic was found to vary in these organs (8). Arsenic induced nephrotoxicity results in disturbing the antioxidant defense system, protein oxidation and lipid peroxidation products. It also leads to renal functional deterioration (9). Though, its high affinity for sulphydryl groups of protein has a tendency to readily react with the sulfhydryl groups of proteins and this turn inhibit biochemical pathways and considered to be the biologically active form and the major source to arsenic toxicity (10). Lipid peroxidation leading to decrease glomerular filtration rate and to elevate nitrogenous waste such as urea, uric acid and creatinine $(11,12)$. 8-OHdG is formed from deoxyguanosine in DNA by hydroxyl free radicals. Because of its stability, 8-OHdG is known as one of the most reliable markers of oxidative DNA damage (13).

Recent studies have implicated the endogenous signaling molecule called adenosine in renal function. Adenosine is produced by enzymatic phosphohydrolysis of its precursor molecules, particularly adenosine triphosphate (ATP) and Adenosine monophosphate (AMP) $(14,15,16)$. Hence, inhibition of ADA activity has been proposed to be a good therapeutic approach for the management or prevention of kidney dysfunction.

Carica papaya belongs to the family of Caricaceae. Papaya is an herbaceous succulent plant that possess selfsupporting stems (17). It is a large perennial herb with a swift growth rate. The plants are usually short-lived, but can produce fruit for more than 20 years (18). The papaya has a rather complex means of reproduction. The plant was originally derived from the southern part of Mexico. C. papaya is a perennial plant, and it is presently distributed over the whole tropical area. In particular, C. papaya fruit circulates widely, and it is accepted as food. In Nigeria, pawpaw is one of the most popular, cheapest, economically important fruit tree grown and consumed for its nutritional content (19). Papaya is not a tree but an herbaceous succulent plant that possesses self-supporting stems (17). The top ten countries that produces Carica papaya plants worldwide are; Brazil (25\%), Nigeria (15\%), India (12\%), Mexico (11\%), Indonesia (10\%), Ethiopia (4\%), Congo (4\%), Peru (3\%), Venezuela (3\%), and lastly China (2\%) (FAO, 2004). Hence, this study investigated the effect of Carica papaya root extract on the sodium arsenite-renal inflammation through inhibition of anti-inflammatory biomarkers.

\section{MATERIALS AND METHODS}

\section{Plant material}

Roots of C. papaya Linn. was freshly collected in May, 2016 from Ijadu farm, Ado-Ekiti, Ekiti State, Nigeria. The plant was identified and authenticated by a senior taxonomist at the herbarium unit of the Department of Biological Science, Afe Babalola University, Ado-Ekiti, Nigeria and a voucher specimen number ABUAD/040 was deposited accordingly. All plant names in this manuscript are formatted according to the latest revision in "The Plant List", and correspond to the good practices in publishing studies on herbal materials, as described by (20).

\section{Preparation of aqueous extract of C. papaya root}

The aqueous extract of the powered C. papaya root was prepared using method described previously (12). The roots were air-dried in the laboratory at ambient temperature $\left(30 \pm 2{ }^{\circ} \mathrm{C}\right)$ for 28 days, minced using a laboratory mechanical grinder and the powders obtained stored until further use. $50 \mathrm{~g}$ of the powdered sample were extracted with distilled water (via maceration) for $48 \mathrm{~h}$. The percentage yield extraction calculated as follows:

$$
\begin{aligned}
& \text { \% yield }=\quad \text { Weight of the dry extract } \\
& \text { Weight of powdered leaves }
\end{aligned}
$$

\section{Experimental Animals}

Eight weeks old male albino rats of Wistar stain with initial mean body weight (bw) (155.25 $\pm 11.52 \mathrm{~g})$ were used in this study. The animals were obtained from Animal house, Afe Babalola University, Ado-Ekiti, Ekiti State, Nigeria. The animals were housed in large clean spacious cages and were given food and water ad libitum. The animal room was well ventilated with a $12 \mathrm{~h}$ light/dark cycle, throughout the period of the experiment. They were fed ad libitum on rat pellets (Top Feeds, Nigeria) and water. The handling of animals was conformed to the standards 
of National Institute of Health (NIH publication 85-23, 1985) for experimental animal maintenance. Animals were maintained according to the rules and regulations of the Experimental Animal Research Ethics Committee of Afe Babalola University, Ado-Ekiti, Ekiti State, Nigeria (Ethical approval number: ABUAD/ACA/121).

\section{Animal distribution}

Animals were randomly divided into five groups as follows: Group I Rats that received vehicles alone (served as control), Group II Rats that received arsenic as sodium arsenite in drinking water at a concentration of $100 \mathrm{ppm}$. Group III Rats that were treated with arsenic along with ascorbic acid ( $200 \mathrm{mg} / \mathrm{kg}$ body wt. dissolved in water) given by oral gavage once a day. Group IV Rats that were given arsenic along with aqueous extract of $C$. papaya roots (100 $\mathrm{mg} / \mathrm{kg}$ bw) by oral gavage once a day. Group V Rats that were administered arsenic along with aqueous extract of C. papaya roots $(150 \mathrm{mg} / \mathrm{kg} \mathrm{bw})$ by oral gavage once a day for 21 days.

\section{Isolation of blood and organs}

At the end of the experimental period, animals were euthanized by diethyl ether and blood and organ samples were collected. The whole blood of each animal was collected via cardiac puncture and immediately preserved in a refrigerator until further processing. The blood samples were centrifuged at $3000 \mathrm{rpm}$ for $15 \mathrm{~min}$ and serum from each blood sample was separated and preserved at $-30{ }^{\circ} \mathrm{C}$ for further analysis. The kidney was collected from each animal, washed with normal saline, wiped with filter paper, weighed and preserved at $-30{ }^{\circ} \mathrm{C}$ until subsequent analysis.

\section{Estimation of Plasma 8-hydroxy-2'-deoxyguanosine} (8-OHdG)

Blood Plasma samples from each group were diluted twice and filtered through $20 \mu \mathrm{m}$ filters and subsequently filtered sample was used for 8-OHdG analysis. The 8-OHdG analysis was performed using the NWLSTM 8-OHdG ELISA kit (Northwest Life Science Specialties, LLC, Vancouver, WA). The protein content in each sample was estimated using DC protein Assay kit. The result was expressed as 8-OHdG (ng/mg of protein).

\section{Estimation of Adenosine deaminase}

ADA activity determination was performed as method described previously (21) which is based on the direct measurement of the formation of ammonia, produced when adenosine deaminase acts in excess of adenosine. $50 \mu \mathrm{L}$ of kidney homogenates reacted with $21 \mathrm{mmol} / \mathrm{L}$ of adenosine, $\mathrm{pH} 6.5$, and was incubated at $37{ }^{\circ} \mathrm{C}$ for 60 $\mathrm{min}$. The protein content used for the platelet experiment was adjusted to between 0.7 and $0.9 \mathrm{mg} / \mathrm{mL}$. Results were expressed in units per liter (U/L). One unit (1 U) of ADA is defined as the amount of enzyme required to release 1 mmol of ammonia per minute from adenosine at standard assay conditions.

\section{Assay for Serum C-reactive Protein}

Serum C-reactive protein (CRP) was measured according to the method described previously (22) by ELISA technique using kits purchased from DIA MED (Belgium).

\section{Quantification of Nitric Oxide (NO)}

Nitric Oxide content in kidney homogenates was estimated in a medium containing $400 \mathrm{~mL}$ of $2 \%$ vanadium chloride $\left(\mathrm{VCl}_{3}\right)$ in $5 \% \mathrm{HCl}, 200 \mathrm{~mL}$ of $0.1 \% \mathrm{~N}$-(l-naphthyl) ethylenediaminedihydrochloride, and $200 \mathrm{~mL}$ of $2 \%$ sulfanilamide (in $5 \% \mathrm{HCl}$ ). After incubating at $37^{\circ} \mathrm{C}$ for 60 minutes, nitrite levels, which correspond to an estimative of levels of NO, was determined spectrophotometrically at $540 \mathrm{~nm}$, based on the reduction of nitrate to nitrite by $\mathrm{VCl}_{3}$ using method described previously (23). Kidney nitrite and nitrate levels were expressed as nanomoles of NO per milligram of protein.

\section{Assay of Serum Inducible Nitric Oxide Synthase (iNOS) enzymatic activity}

The activity of iNOS in the serum was measured by an iNOS activity assay kit according to the manufacturer's instructions (Beyotime Institute of Biotechnology) using a fluorescence microplate reader with excitation/emission wavelength of $495 / 515 \mathrm{~nm}$.

\section{Determination of Pro-Antioxidant Marker}

The non-antioxidant markers such as malonaldehyde (MDA) was measured via adopting the method described previously (24).

\section{Estimation of arsenic}

Tissue/blood samples were digested according to the method described previously (25). To $100 \mathrm{mg}$ of tissues/1 $\mathrm{ml}$ of blood, $1 \mathrm{ml}$ of concentrated nitric acid was added, followed by $1 \mathrm{ml}$ of perchloric acid. The sample was then digested over a sand bath until the solution turned yellow in color. If the color of the digest was brown, more nitric acid and perchloric acid were added and the oxidation was repeated. The digest was made up to known volume with deionized water. Aliquots of this were used to estimate arsenic by using the atomic absorption spectrophotometer. The concentration of arsenic was expressed as $\mu \mathrm{g} / \mathrm{dl}$ blood or $\mu \mathrm{g} / \mathrm{g}$ tissue.

\section{Data analysis}

Data are presented as the mean \pm SEM $(n=7)$. Data were analyzed by using a statistical software package (SPSS for Windows, version 20.0, IBM Corporation, NY, USA) using One-Way ANOVA, Duncan multiple range post-hoc test (DMRT). Values were considered significantly different at $p<0.05$

\section{RESULTS}

The result for the marker of DNA in serum are presented in Fig 1. The 8-OHdG level was significantly $(p<$ 


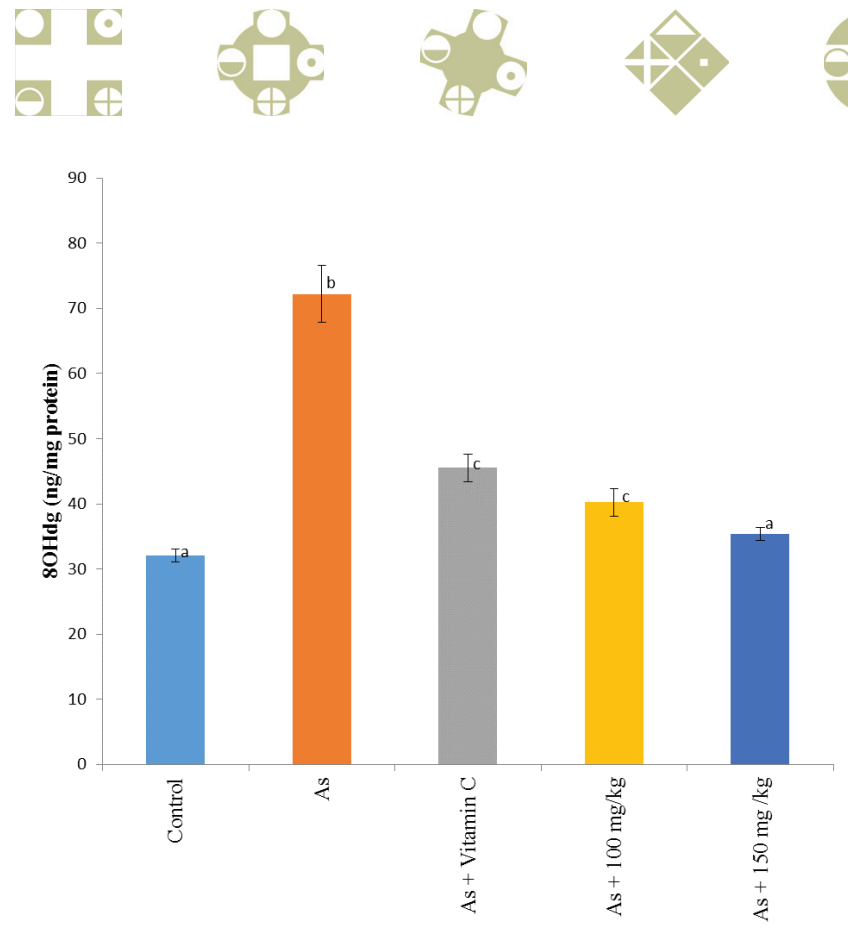

Figure 1: Effect of aqueous extract of C. papaya roots and arsenic in the levels of serum 8-OHdG level (ng/mg protein) of control and experimental rats. Values are mean \pm SEM for 7 rats in each group. Values not sharing a common superscript letter $(\mathrm{a}-\mathrm{c})$ differ significantly at $\mathrm{p}<0.05$ (DMRT), As; Arsenic.

0.05) increased in arsenic treated rats compared to normal control rats. However, treatment with aqueous extract of C. papaya root at $100 \mathrm{mg} / \mathrm{kg}$ body weight and $150 \mathrm{mg} / \mathrm{kg}$ body weight significantly decreased the level of 8-OHdG in serum compared with arsenic untreated rats. Vitamin $C$ administration significantly decreased the levels of 8-OHdG $(p<0.05)$ (Fig.1). These effects were found to be pronounced in the arsenic $+150 \mathrm{mg} / \mathrm{kg}$ body weight $C$. $p a-$ paya root aqueous extract.

The data for adenosine deaminase (ADA) in serum are presented in Fig 2. As seen from the (Figure 2), ADA activity was significantly higher in arsenic only treated rats $(p<0.05)$ compared to normal control rats. Treatment with aqueous extract of $C$. papaya root at $100 \mathrm{mg} / \mathrm{kg}$ body weight and $150 \mathrm{mg} / \mathrm{kg}$ body weight all exerted significant decrease inhibitions $(p<0.05)$ on the ADA activity compared with arsenic untreated rats. Vitamin $C$ administration significantly decrease ADA activity $(p<0.05)$.

The data for serum C-reactive protein (CRP) are presented in Fig 3. The serum C-reactive protein concentration was significantly higher in arsenic untreated rats compared to normal control rats $(p<0.05)$. Treatment with aqueous extract of $C$. papaya root at $100 \mathrm{mg} / \mathrm{kg}$ body weight and $150 \mathrm{mg} / \mathrm{kg}$ body weight significantly decreased $(p<0.05)$ the concentration of serum C-reactive protein compared with arsenic untreated rats. Vitamin $\mathrm{C}$ administration significantly decreased concentration of serum Creactive protein $(p<0.05)$ (Fig.3).

The levels of nitric oxide (NO) as a measure of enhanced oxidative stress has been measured and presented in Fig 4. Rat exposed to arsenic exhibited significant decrease in nitric oxide levels compared to normal control

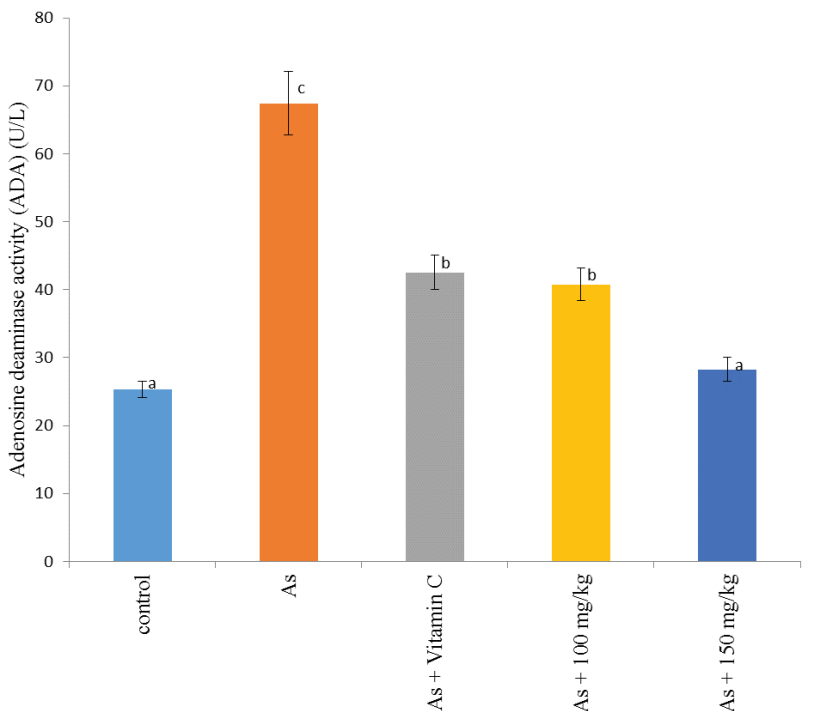

Figure 2: C. papaya root inhibited Adenosine deaminase (ADA) enzymatic activity (U/L) of control and experimental rats. Values are mean \pm SEM for 7 rats in each group. Values not sharing a common superscript letter $(\mathrm{a}-\mathrm{c})$ differ significantly at $\mathrm{p}<0.05$ (DMRT), As; Arsenic.

$(p<0.05)$. Simultaneous treatment with aqueous extract of C. papaya root at $100 \mathrm{mg} / \mathrm{kg}$ body weight and $150 \mathrm{mg} /$ $\mathrm{kg}$ body weight and vitamin $\mathrm{C}$ significantly increases the nitric oxide levels $(p<0.05)$ in serum compared to those treated with arsenic alone (Fig. 4).

Furthermore, the inhibitory effect of aqueous extract of $C$. papaya root on the activity of iNOS enzyme was examined. As shown in Fig. 5, arsenic untreated rats caused a significant $(p<0.05)$ increment of iNOS enzymatic activity compared to normal control. Administration of aqueous extract of C. papaya root at $100 \mathrm{mg} / \mathrm{kg}$ body weight and $150 \mathrm{mg} / \mathrm{kg}$ body weight and vitamin $C$ strongly inhibited $(p<0.05)$ the iNOS enzymatic activation in arsenic treated rats compared to arsenic alone.

As shown in Figure 6, compared with the control group, arsenic significantly increased $(p<0.05)$ the levels of MDA in arsenic untreated rats compared to normal control. When aqueous extract of C. papaya root at 100 $\mathrm{mg} / \mathrm{kg}$ body weight and $150 \mathrm{mg} / \mathrm{kg}$ body weight and vitamin $\mathrm{C}$ was administered to arsenic, the levels of MDA were significantly reduced $(p<0.05)$ compared to arsenic untreated rats.

The arsenic concentrations in blood and kidney tissue are present in Figure 7. Results showed that arsenic accumulated preferentially in the kidney and serum. Arsenic concentrations in the blood and kidney tissues were significantly higher $(p<0.05)$ in arsenic untreated rats compared to normal control rats. Administration with 100 $\mathrm{mg} / \mathrm{kg}$ body weight of $C$. papaya root aqueous extract and $150 \mathrm{mg} / \mathrm{kg}$ body weight of C. papaya root aqueous extract groups and vitamin $C$ significantly $(p<0.05)$ decreased the concentrations. 


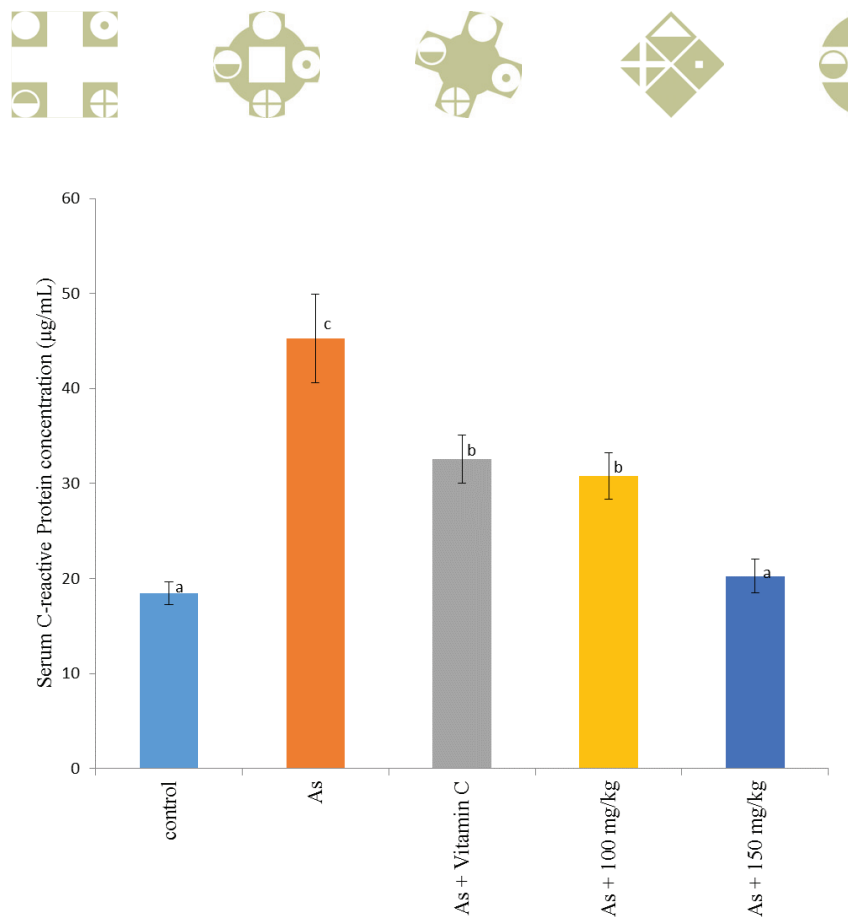

Figure 3: C. papaya root effect on Serum C-reactive protein concentration $(\mu \mathrm{g} / \mathrm{mL})$ of control and experimental rats. Values are mean $\pm \mathrm{SEM}$ for 7 rats in each group. Values not sharing a common superscript letter (ace) differ significantly at $\mathrm{p}<0.05$ (DMRT), As; Arsenic.

\section{DISCUSSION:}

At the moment, therapeutic options to prevent or manage acute renal injury associated with heavy metal poisoning are tremendously restricted, hence, the look for novel therapeutic interventions is an area of intense investigation. 8-OHdG, may be a novel biomarker for arsenic-induced renal inflammation and oxidative stress. It was reported that elevated levels of $8-\mathrm{OHdG}$ in plasma will cause DNA damage in arsenic exposed rats (26). In this study, levels of 8-OHdG in plasma from arsenic only treated rats were significantly increased compared to control rats, which is similar to the reports of (26). Increased levels of 8-OHdG could also be as a result of oxidative stress induced by the arsenic (27). Treatment with C. papaya root aqueous extract at 150 and $100 \mathrm{mg} / \mathrm{kg}$ body weight respectively, or vitamin $\mathrm{C}$, to arsenic-induced rats considerably reduced the 8-OHdG levels in rat plasma compared to arsenic only rats which might be due to the antioxidant activities of $C$. papaya root and its ability to ameliorate oxidative stress induced by arsenic as well as present phytochemical components such as phenolic, flavonoids and saponins (28).

Of recent, studies involve the endogenous signal molecule adenosine in renal function or protection. Thus, enzymatic production of nucleoside adenosine from its precursor molecules adenosine triphosphate and adenosine monophosphate, and regulation of its level by ADA play a vital role in decreasing renal damage and conserving the functionality of the kidney during incidents of renal heavy metal poisoning $(15,16)$. The results of this study revealed that ADA activity was considerably increased in the kidney of arsenic only treated rats compared with the control $(p<0.05)$. Earlier researches have confirmed upregulation

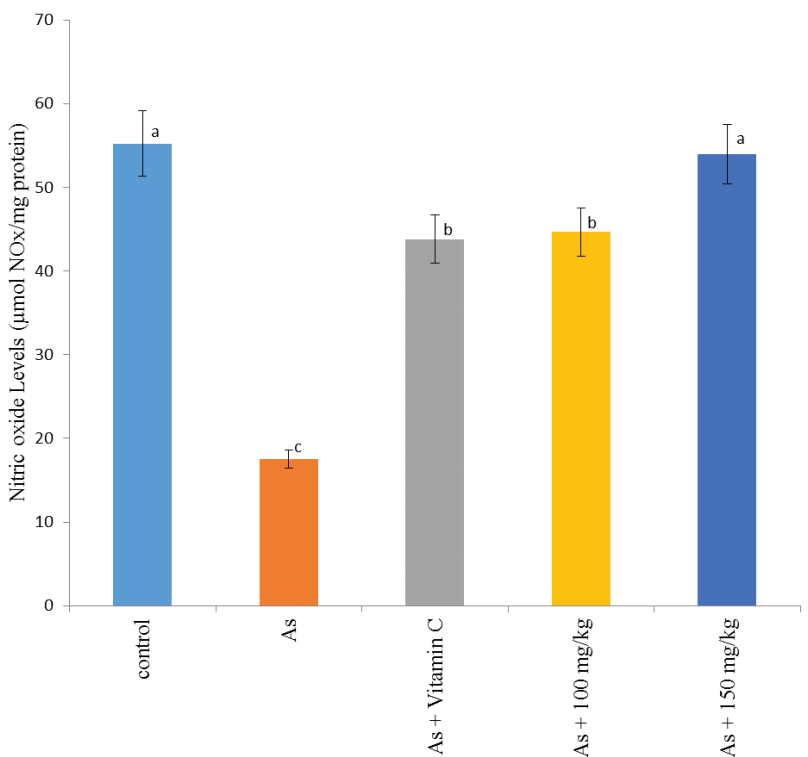

Figure 4: C. papaya root effect on the levels of nitric oxide (NO) ( $\mu \mathrm{mol}$ $\mathrm{NOx} / \mathrm{mg}$ protein) of control and experimental rats. Values are mean \pm SEM for 7 rats in each group. Values not sharing a common superscript letter $(\mathrm{a}-\mathrm{c})$ differ significantly at $\mathrm{p}<0.05$ (DMRT), As; Arsenic.

in the ADA activity in renal injury $(29,30,31)$. Hence, increase ADA activity found in this study might lead to a reduction in the level of adenosine, a renoprotector molecule $(15,16)$. Numerous studies have linked the levels of adenosine in hypoxia, inflammation, or acute renal injury $(15,32)$. Treatment with aqueous $C$. papaya roots was able to prevent an increase in ADA activity in arsenic-treated rats (Figure 2). This implies that aqueous C. papaya roots

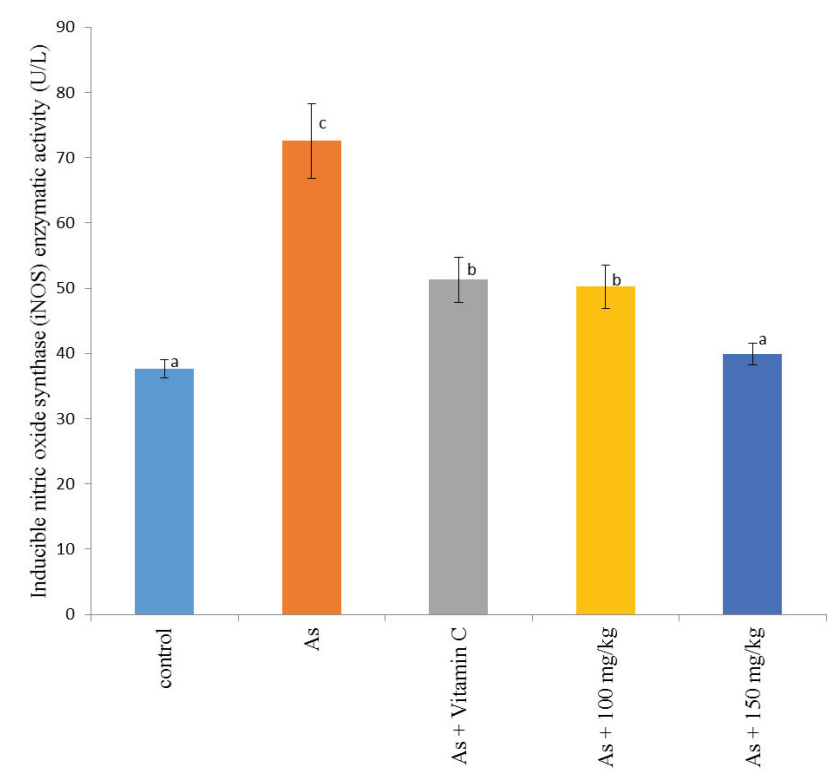

Figure 5: C. papaya root inhibited inducible nitric oxide synthase (iNOS) enzymatic activity (U/L) of control and experimental rats. Values are mean \pm SEM for 7 rats in each group. Values not sharing a common superscript letter $(\mathrm{a}-\mathrm{c})$ differ significantly at $\mathrm{p}<0.05$ (DMRT), As; Arsenic. 


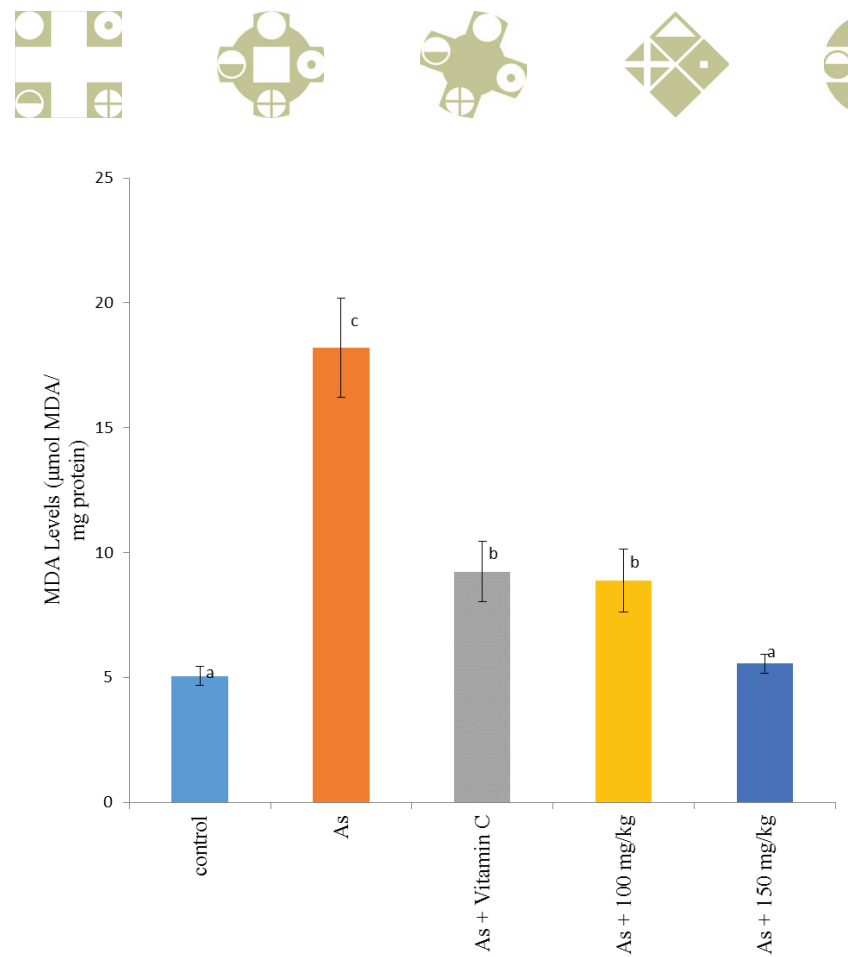

Figure 6: $C$. papaya root effect MDA levels ( $\mu \mathrm{mol} \mathrm{MDA} /$ protein) of control and experimental rats. Values are mean \pm SEM for 7 rats in each group. Values not sharing a common superscript letter $(\mathrm{a}-\mathrm{c})$ differ significantly at $\mathrm{p}<0.05$ (DMRT), As; Arsenic.

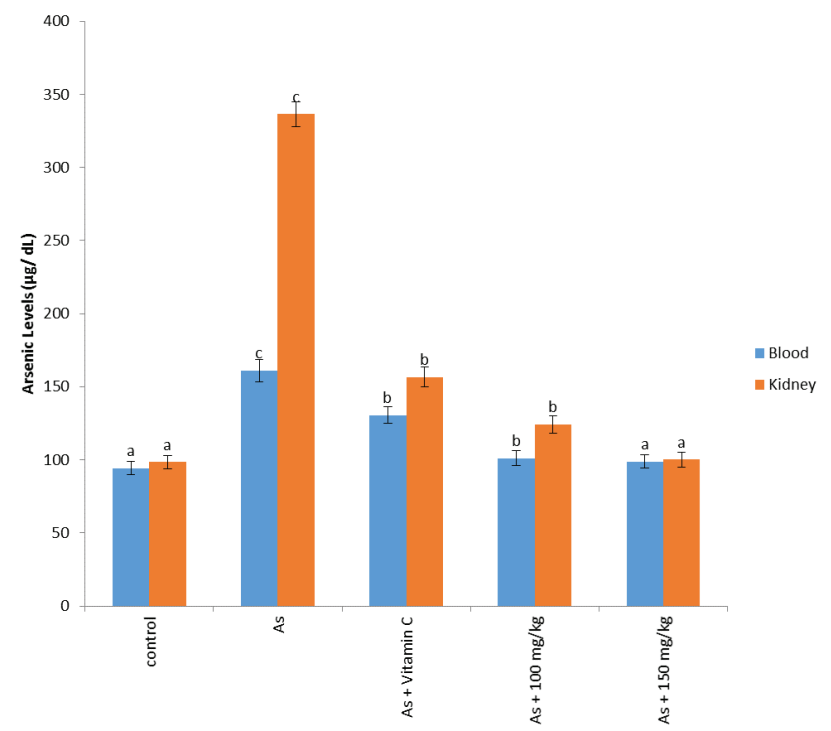

Figure 7: C. papaya root effect Arsenic levels ( $\mu \mathrm{g} / \mathrm{dL}$ ) of control and experimental rats. Values are mean \pm SEM for 7 rats in each group. Values not sharing a common superscript letter $(\mathrm{a}-\mathrm{e})$ differ significantly at $\mathrm{p}<$ 0.05 (DMRT), As; Arsenic.

has a protective role against arsenic poisoning, and also the probable mechanism may well be because of their inhibitory effect on renal ADA activity, thereby leading to an increase in the level of adenosine.

Cytokines synthetized by neutrophils and macrophages stimulate the production of acute-phase proteins, like C-reactive protein (CRP). CRP is synthesized by the hepatocytes. CRP levels in serum increase during infection and inflammation (33). C-reactive protein is a marker, which appears during the late phase of infection $(34,35)$. In the present
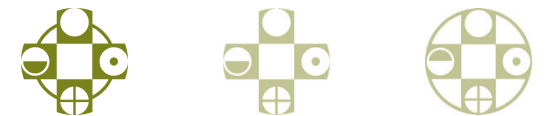

study rats chronically exposed to a wide range of arsenic concentrations through drinking water, arsenic exposure was associated with increased serum CRP levels in arsenictreated rats compared with the control $(p<0.05)$ (Figure $3)$. Arsenic exposure has been proven to cause inflammation; this may be a mechanism for arsenic-induced diseases, as inflammation is involved in the pathogenesis of many chronic diseases, including cardiovascular disease, metabolic syndrome (36), chronic kidney disease (37), and cancer (38). Chronic exposure of rats to $100 \mathrm{ppm}$ sodium arsenite in drinking water resulted in an increase in the acute-phase protein C-reactive protein (CRP) in the kidney (39).

In this present study, it revealed a significant decrease in the levels of nitric oxide (NO) in arsenic-induced renal injury (Figure 4). Though, treatment with aqueous C. papaya roots, restores the level of $\mathrm{NO}$ in arsenic treated rats. This increase in nitric oxide could be a result of the fact that $C$. papaya roots exhibited an inhibitory effect on the activity (40). However, an increasing evidence that nitric oxide, a potent vasodilator, is one amongst the foremost crucial paracrine modulators and mediators in the regulation of renal functions, for examples total and regional renal blood flow, renal autoregulation, glomerular filtration rate, renin secretion, and salt excretion (41). Nitric oxide also plays a vital role in the pathogenesis of several renal syndromes, for instance diabetic nephropathy, inflammatory glomerular disorders, acute renal failure, and nephrotoxicity of drugs or heavy metals, assigning both beneficial effects through its hemodynamic functions (41).

Aqueous C. papaya roots inhibits arsenic induced expression of inflammation markers inducible nitric oxide synthase (iNOS) activity. In this study, arsenic untreated rats caused a significant $(p<0.05)$ increment of iNOS enzymatic activity compared to normal control (Figure 5). Though, treatment with aqueous extract of C. papaya root at $100 \mathrm{mg} / \mathrm{kg}$ body weight and $150 \mathrm{mg} / \mathrm{kg}$ body weight and vitamin C strongly inhibited $(p<0.05)$ the iNOS enzymatic activation in arsenic treated rats compared to arsenic alone. This result is in agreement with Figure 4, where we observed a decrease in the levels of nitric oxide in arsenic treated rats (42).

The mechanism of arsenic-induced oxidative stress involves an imbalance between generation and removal of reactive oxygen species in tissues and cellular elements, inflicting harm to membranes, DNA, and proteins (43). Reactive oxygen species generated by arsenic initiate lipid peroxidation of the membrane-bound polyunsaturated fatty acids, resulting in impairment of the membrane structural and functional integrity, an interaction between free radicals of numerous pedigrees and unsaturated fatty acids that are typical in membrane lipids. Degradation of polyunsaturated fatty acids in cell bio-membranes by reactive oxygen species, induced by arsenic, ends up in the destruction of bio-membranes and therefore the formation of thiobarbituric acid reactive species, MDA, or conjugated dienes as indicators of lipid peroxidation $(44,45)$. In this study, the level of MDA was measured as an indicator of lipid peroxidation (Figure 6). The level of MDA was considerably increased in the kid- 
ney tissue of arsenic treated rats. The experimental findings suggest that oxidative stress plays a very crucial role in arsenic-induced renal injuries. Our result is in accordance with other findings $(44,45,46,47)$. The increased MDA levels in renal tissue is a sign of over accumulation of lipid peroxides in tissue, causing overconsumption.

Statistics generated revealed that arsenic accumulated preferentially in the kidney tissues. Arsenic concentrations in the kidney tissues (Figure 7) were considerably higher $(p<$ $0.05)$ in arsenic treated rats alone. However, treatment with C. papaya root aqueous extract at 150 and $100 \mathrm{mg} / \mathrm{kg}$ body weight considerably decrease the levels of arsenic in the tissues. Vitamin C administration also reduced the levels of arsenic in the tissues compared to the arsenic-only exposed rats. These results are in accordance with results reported by (48) which showed that arsenic dispersal in tissues depends on the route of administration and its form.

\section{CONCLUSION}

In conclusion, C. papaya roots halts arsenic-induced renal inflammation by inhibiting anti-inflammatory biomarkers in the kidney. Hence, these activities could suggest some probable mechanisms of action for its renoprotective activity.

\section{Acknowledgment}

The Authors wish to acknowledge the Department of Biochemistry, Afe Babalola University for providing the necessary facilities to carry out this study.

\section{Funding}

This research was self-funded without any inputs from private or public commercials.

\section{Declaration of Conflict of Interest}

We declare that we have no conflict of interest.

\section{REFERENCES}

1. IARC (International Agency for Research on Cancer). Monographs on evaluation of carcinogenic risk to humans. In: Some Drinking Water Disinfectants and Contaminants, including Arsenic. 2004; 84: 269-477.

2. Agency for Toxic Substances and Disease Registry (ATSDR). Toxicological Profile for Arsenic TP-92/09, Center for Disease Control, Atlanta, Georgia, 2000.

3. Vahter M, Concha G (2001) Role of metabolism in arsenic toxicity. Pharmacol Toxicol. 2001; 89 (1): 1-5.

4. Rossman TG, Uddin AN, Burns FJ. Evidence that arsenic acts as a cocarcinogen in skin cancer. Toxicol Appl Pharmacol. 2004; 198 (3):394-404.

5. Tchounwou PB, Centeno JA, Patlolla AK. Arsenic toxicity, mutagenesis, and carcinogenesis - a health risks assessment and management approach. Mol Cell Biochem. 2004; 255(1- 2): 47-55.
6. Valko M, Leibfritz D, Moncol J, et al. Free radicals and antioxidants in normal physiological functions and human disease. Int J Biochem Cell Biol. 2007; 39, 44-84.

7. Kotyzová D, Bludovská M, Eybl E. Differential influences of various arsenic compounds on antioxidant defense system in liver and kidney of rats. Environ Toxicol Pharmacol. 2013; 36 (3): 1015-1021.

8. Sohini S, Rana SVS. Amelioration of arsenic toxicity by L-ascorbic acid in laboratory rat. J Environ Biol. 2007; 28 (2):377-384.

9. Patel HV, Kalia K. Sub chronic arsenic exposure aggravates nephrotoxicity in experimental diabetic rats. Ind J Exper Biol. 2010; 48: 762-768.

10. Flora SIS, Mittal M, Mehta A. Heavy metal induced oxidative stress \&its possible reversal by chelation therapy. Ind J Med Res. 2008; 128: 501-523.

11. Saxena PN, Anand S, Saxena N, et al. Effect of arsenic trioxide on renal functions and its modulation by Curcuma aromatica leaf extract in albino rat. J Environ Biol. 2009; 30 (4):527-531.

12. Ojo OA, Oyinloye BE, Ajiboye BO, et al. Dichlorvos Induced Nephrotoxicity in Rat Kidney: Protective Effects of Alstonia boonei Stem Bark. Int J Pharmacog. 2014a; 1(7): 429-437.

13. Subash PP, Gurumurthy A, Sarasabharathi KM, et al. Urinary 8-oHdG: A marker of oxidative stress to DNA and Total Antioxidant status in essential hypertension with south Indian population. Ind J Clin Biochem. 2010; 25(2): 127.

14. Hart ML, Much C, Gorzolla IC, et al. Extracellular adenosine production by ecto- 5 '-nucleotidase protects during murine hepatic ischemic preconditioning. Gastroenterol. 2008; 135:1739-50.

15. Bauerle JD, Grenz A, Kim JH, et al. Adenosine generation and signaling during acute kidney injury. J Am Soc Nephrol. 2011; 22:14-20.

16. Ramani K, Tomasi ML, Yang H et al. (2012) Mechanism and significance of changes in glutamate-cysteine ligase expression during hepatic fibrogenesis. J Biol Chem. 2012; 287:36341-55.

17. Dick G." Papaya”: A tantalising taste of the Tropics. Maricopa County Master Gardener Volunteer information, University of Arizona Cooperative Extension, 2003.

18. Ayoola PB, Adeyeye A. Phytochemical and Nutrient evaluation of Carica papaya (Pawpaw) Leaves. Int J Res Rev Appl Sci. 2010; 5 (3).

19. Baiyewu RA, Amusa NA. The Effect of temperature and Relative Humidity on pawpaw fruit rot in SouthWestern Nigeria. Wr J Agric Sci. 2005; 1(1): 80-83.

20. Chan K, Shaw D, Simmonds MS, Leon CJ, Xu Q, Lu A, Sutherland I, Ignatova S, Zhu YP, Verpoorte R, Williamson EM, Duez P. Good practice in reviewing and publishing studies on herbal medicine, with special emphasis on traditional Chinese medicine and Chinese materia medica. J Ethnopharmacol. 2012; 140(3):469-75.

21. Guisti G, Galanti B. Colorimetric method. In: Bergmeyer HU (eds) Methods of enzymatic analysis. Verlag Chemie, Weinheim, 1984; 315-323. 
22. Ben-Assayag E, Shenhar-Tsarfaty S, Bova I, et al. Triggered C-reactive protein $(\mathrm{CRP})$ concentrations and the CRP gene $-717 A>G$ polymorphism in acute stroke or transient ischemic attack. Euro J Neurol. 2007; 14: 315-320.

23. Morakino AO, Adeniyi OS, Arikawe AP. Effects of Zingiber officinale on reproductive functions of the male rat. African J Biomed Res. 2008; 2:329 - 339.

24. Varshney R, Kale RK. Effects of calmodulin antagonists on radiation-induced lipid peroxidation in microsomes. Int J Radia Biol. 1990; 58: 733-43.

25. Ballentine R, Burford DD. Determination of metals. Methods Enzymol. 1957; 3: 1002-1035.

26. Nain S, Smits JEG. Pathological, immunological and biochemical markers of subchronic arsenic toxicity in rats. Environ Toxicol. 2012; 27 (4):244-254

27. Kitchin KT. Recent advances in arsenic carcinogenesis: modes of action, animal model systems, and methylated arsenic metabolites. Toxicol Appl Pharmacol. 2001; 172 (3): 249-261.

28. Bamisaye FA, Ajani EO, Minari JB. Prospects of Ethnobotanical Uses of Pawpaw (Carica Papaya). Journal of Medicinal Plants Studies. 2013; 1(4): 171-177

29. Spanevello RM, Mazzanti CM, Kaizer R, et al. Apyrase and 5 '- nucleotidase activities in synaptosomes from the cerebral cortex of rats experimentally demyelinated with ethidium bromide and treated with interferon-b. Neurochem Res. 2006; 31:455-62.

30. Kaizer RR, Maldonado PA, Spanevello RM, et al. The effect of aluminium on NTPDase and $5^{\prime}$-nucleotidase activities from rat synaptosomes and platelets. Int J Dev Neurosci. 2007; 25:381-6.

31. Schmatz R, Schetinger MRC, Spanevello RM, et al. Effects of resveratrol on nucleotide degrading enzymes in streptozotocin induced diabetic rats. Life Sci. 2009; 84:345-50.

32. Grenz A, Zhang H, Eckle T, et al. Protective role of ecto-5'-nucleotidase (CD73) in renal ischemia. J Am Soc Nephrol. 2007; 18:833-45.

33. Qu J, Lü X, Liu Y, et al. Evaluation of procalcitonin, Creactive protein, interleukin- 6 \& serum amyloid A as diagnostic biomarkers of bacterial infection in febrile patients. Ind J Med Res. 2015; 141: 315- 21.

34. Alghasham A, Salem TA, Meki AM. Effect of cadmium-polluted water on plasma levels of tumor necrosis factor-a, interleukin- 6 and oxidative status biomarkers in rats: Protective effect of curcumin. Food Chem Toxicol. 2013; 59: 160-4.

35. Iraz M, Iraz M, Eşrefoğlu M et al. (2015) Protective effect of $\beta$-glucan on acute lung injury induced by lipopolysaccharide in rats. Turkish J Med Sci. 2015; 45: 261-7.
36. Black PH. The inflammatory response is an integral part of the stress response: implications for atherosclerosis, insulin resistance, type II diabetes and metabolic syndrome X. Brain Behavioural Immunity. 2003; 17:350-364.

37. Leemans JC, Kors L, Anders HJ, et al. Pattern recognition receptors and the inflammasome in kidney disease. Nature Reviews Nephrol. 2014; 10:398-414.

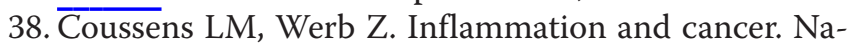
ture. 2002; 420:860-867.

39. Druwe IL, Sollome JJ, Sanchez-Soria P, et al. Arsenite activates NF-kappa B through induction of C-reactive protein. Toxicol Appl Pharmacol, 2012; 261:263-270.

40. Bounaama A, Djerdjouri B, Laroche-Clary A, et al. Short curcumin treatment modulates oxidative stress, arginase activity, aberrant crypt foci, and TGF-b1 and HES-1 transcripts in 1,2-dimethylhydrazine-colon carcinogenesis in mice. Toxicol. 2012; 302:308-17.

41. Ghasemi M, Nematbakhsh M, Daneshmand F, et al. A. Role of nitric oxide in kidney and liver (as distance organ) function in bilateral renal ischemia-reperfusion: effect of L-arginine and NG-nitro-L-arginine methyl ester. Adv Biomed Res. 2015; 4:233.

42. Southan GJ, Szabó C. Selective pharmacological inhibition of distinct nitric oxide synthase isoforms. Biochem Pharmacol. 1996; 51 (4): 383-94.

43. Yang H, Shu Y. Cadmium transporters in the kidney and cadmium-induced nephrotoxicity. Int J Mole Sci. 2015; 16:1484-94.

44. Ojo OA, Oyinloye BE, Ajiboye BO, et al. Dichlorvos induced oxidative stress in rat brain: Protective effects of Ethanolic extract of Alstonia boonei stem bark. Asian J Pharmaceutics. 2014b; 8(4):216-221

45. Esrefoglu M, Gul M, Ates B, et al. Ultrastructural clues for the protective effect of ascorbic acid and $\mathrm{N}$ acetylcysteine against oxidative damage on caerulein induced pancreatitis. Pancreatol. 2006; 6:477-85.

46. Oyinloye BE, Ajiboye BO, Ojo OA, et al. (2016) Cardioprotective and antioxidant influence of aqueous extracts from Sesamum indicum seeds on oxidative stress induced by cadmium in Wistar rats. Pharmacog Mag. 2016; 12(46): S170-S174.

47. Ojo OA, Ajiboye BO, Oyinloye BE, et al. Protective Effect of Irvingia gabonensis stem bark extract on Cadmium-Induced Nephrotoxicity in rats. Interdiscip Toxicol. 2015; 7(4): 208-214.

48. Miltonprabu S, Sumedha NC. Arsenic induced biochemical and genotoxic effects and its amelioration by diallyl trisulphide in rats. Int J Adv Res. 2013; 1(7): 175-184. 